\title{
Ancient pre-glacial erosion surfaces preserved beneath the West Antarctic Ice Sheet
}

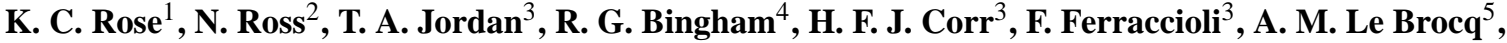 \\ D. M. Rippin ${ }^{6}$, and M. J. Siegert ${ }^{7}$ \\ ${ }^{1}$ Bristol Glaciology Centre, School of Geographical Sciences, University of Bristol, Bristol BS8 1SS, UK \\ ${ }^{2}$ School of Geography, Politics \& Sociology, Newcastle University, Newcastle upon Tyne NE1 7RU, UK \\ ${ }^{3}$ British Antarctic Survey, High Cross, Madingley Road, Cambridge CB3 OET, UK \\ ${ }^{4}$ School of GeoSciences, University of Edinburgh, Edinburgh EH8 9XP, UK \\ ${ }^{5}$ School of Geography, University of Exeter, Exeter EX4 4RJ, UK \\ ${ }^{6}$ Environment Department, University of York, York YO10 5DD, UK \\ ${ }^{7}$ Grantham Institute and Department of Earth Science and Engineering, Imperial College London, \\ London SW7 2AZ, UK
}

Correspondence to: K. C. Rose (kathrynrose100@hotmail.com) and M. J. Siegert (m.siegert@imperial.ac.uk)

Received: 16 June 2014 - Published in Earth Surf. Dynam. Discuss.: 15 July 2014

Revised: 28 January 2015 - Accepted: 2 February 2015 - Published: 16 February 2015

\begin{abstract}
We present ice-penetrating radar evidence for ancient (pre-glacial) and extensive erosion surfaces preserved beneath the upstream Institute and Möller ice streams, West Antarctica. Radar data reveal a smooth, laterally continuous, gently sloping topographic block, comprising two surfaces separated by a distinct break in slope. The erosion surfaces are preserved in this location due to the collective action of the Pirrit and MartinNash hills on ice sheet flow, resulting in a region of slow flowing, cold-based ice downstream of these major topographic barriers. Our analysis reveals that smooth, flat subglacial topography does not always correspond to regions of either present or former fast ice flow, as has previously been assumed. We discuss the potential origins of the erosion surfaces. Erosion rates across the surfaces are currently low, precluding formation via present-day glacial erosion. We suggest that fluvial or marine processes are most likely to have resulted in the formation of these surfaces, but we acknowledge that distinguishing between these processes with certainty requires further data.
\end{abstract}

\section{Introduction}

The Institute and Möller ice streams (IMIS) drain around $20 \%$ of the area of the West Antarctic Ice Sheet (WAIS) (Fig. 1). Despite their significance as fast-flowing outlet glaciers within an ice sheet that is regarded as potentially unstable (Joughin et al., 2014), until recently relatively little was known about the glacial history of this region (Bingham and Siegert, 2007). In order to address this issue, an aerogeophysical survey was undertaken across the ice streams and surrounding locations (Ross et al., 2012). Mapping ice sheet boundary conditions in these little-explored regions is of great importance, as subglacial topography can exert a strong control on ice dynamics (Joughin et al., 2009) and may retain a long-term record of geomorphic processes and ice sheet evolution (Young et al., 2011). Analysis of bed topography can therefore be used to make inferences about the nature and evolution of palaeo-landscapes in Antarctica (Rose et al., 2013).

The IMIS survey has provided a wealth of new information, elucidating the tectonic, topographic and hydrological settings of this region (Ross et al., 2012; Jordan et al., 2013; Le Brocq et al., 2013; Siegert et al., 2014). These, in turn, have contributed to our understanding of early ice inception (Ross et al., 2014) and ice sheet sensitivity in the Weddell Sea sector (Siegert et al., 2013; Wright et al., 2014). The macro-scale geomorphology of the IMIS sector, however, has yet to be considered. In particular, the region between 

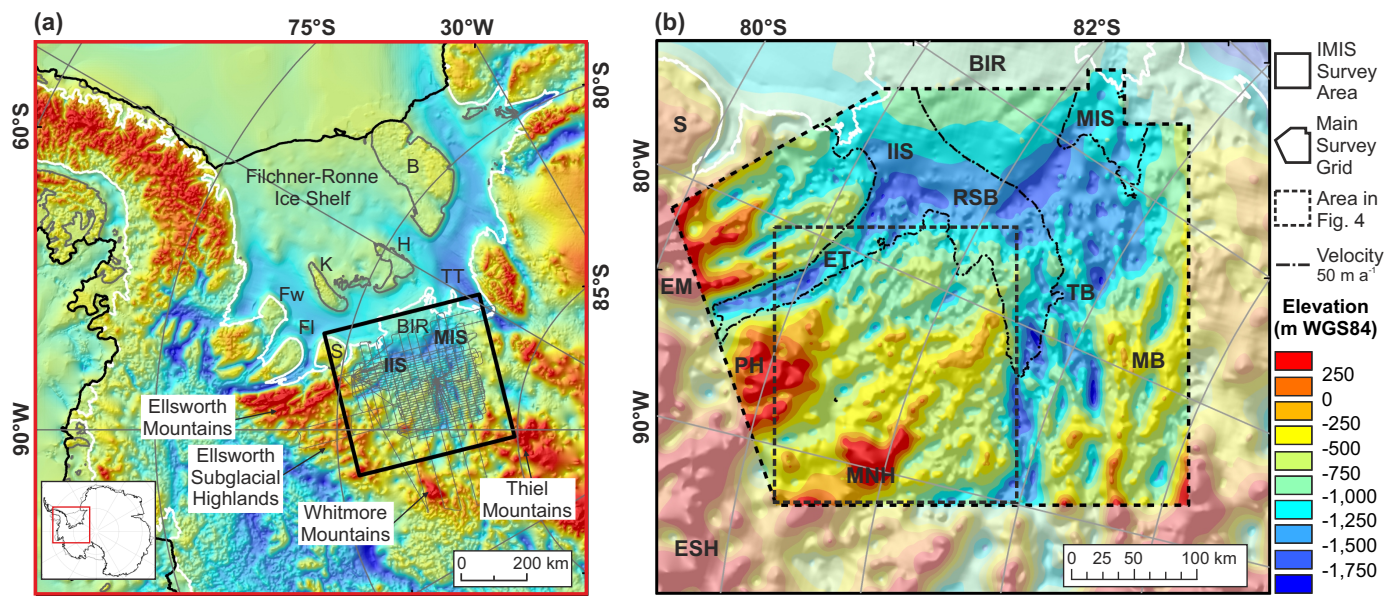

Figure 1. (a) Subglacial topography of the Weddell Sea sector, West Antarctica (Fretwell et al., 2013). The white line marks the grounding line, black line marks the outer ice shelf edge, solid grey lines mark islands, (derived from MODIS MOA imagery; Haran et al., 2005, updated 2013), and light-grey gridded lines mark flight lines from a high-resolution modern airborne survey (Ross et al., 2012). The inset with the red box shows the location of (a) in West Antarctica. (b) Subglacial topography of the Institute and Möller ice streams, derived from IMIS survey (Ross et al., 2012), and overlain on semi-transparent Bedmap2 topography (Fretwell et al., 2013). The 50 $\mathrm{m} \mathrm{a}^{-1}$ ice sheet surface velocity contour is also shown (Rignot et al., 2011). Annotations: B - Berkner Island; BIR - Bungenstock Ice Rise; EM - Ellsworth Mountains; ESH - Ellsworth Subglacial Highlands; ET - Ellsworth Trough; Fl - Fletcher Promontory; Fw - Fowler Peninsula; H - Henry Ice Rise; IIS - Institute Ice Stream; K - Korff Ice Rise; MB - Marginal Basins; MIS - Möller Ice Stream; MNH - Martin-Nash Hills; PH Pirrit Hills; RSB - Robin Subglacial Basin; S - Skytrain Ice Rise; TB - Transitional Basins; TT - Thiel Trough (southerly margin).

the Robin Subglacial Basin and the mountain ranges of the Ellsworth-Whitmore Mountains block has received little attention (Fig. 1). Here, we focus on this striking region, where a zone of apparently flat and smooth topography, located between the deeper elongate troughs and basins that underlie the fast-flowing tributaries of the Institute Ice Stream (IIS), is imaged and mapped. We inspect and analyse the morphology of this sector in order to interpret this feature. We discuss different erosion regimes associated with erosion surfaces and favour a fluvial or marine mechanism of formation. Differentiating between these two processes would require further investigation and additional data (e.g. apatite fission track analysis, offshore seismic and sedimentary records, regional rock outcrop analysis, glacial isostatic adjustment reconstruction). Our findings do, however, provide the foundation from which the evolution of this landscape and its relationship with longterm glacial history may be deciphered.

\section{Regional topographic and geological setting}

The Weddell Sea sector of the WAIS (Fig. 1), in which the IMIS are contained, is characterised by a broad, marine (below sea level) embayment (Ross et al., 2012). The IMIS drain into the Filchner-Ronne Ice Shelf and their lower trunks (0$130 \mathrm{~km}$ upstream of the grounding line) are separated by the Bungenstock Ice Rise (Fig. 1b). The area immediately inland of the Bungenstock Ice Rise is dominated by the $\sim 1.5 \mathrm{~km}$ deep Robin Subglacial Basin. Two primary tributaries feed the fast ice flow $\left(>50 \mathrm{~m} \mathrm{a}^{-1}\right)$ of the IIS (Fig. 1b). One is un- derlain by the linear Ellsworth Trough and the other by the Transitional Basins - a series of major topographic depressions (40-80 km long, $10-20 \mathrm{~km}$ wide, $\sim 1.8-1.9 \mathrm{~km}$ deep) which likely have a tectonic origin and are dispersed in a more complex right-stepping, en échelon pattern (Jordan et al., 2013). In contrast, the onset of fast flow of the Möller Ice Stream (MIS) initiates closer to the grounding line, in proximity to the Robin Subglacial Basin and the northern margin of the Transitional Basins (Fig. 1b). Along the eastern edge of the IMIS survey area, and south-east of the Transitional Basins, lies a series of elongate Marginal Basins (Jordan et al., 2013; Rose et al., 2014). The IMIS are bordered by numerous uplands, including the Ellsworth, Whitmore and Thiel mountains and the Ellsworth Subglacial Highlands (Fig. 1a). The main focus of this paper is the inter-tributary area of the IIS, between the Robin Subglacial Basin and the Pirrit and Martin-Nash hills further inland.

In terms of their geological setting, the upper parts of the IMIS flow over the Ellsworth-Whitmore Mountains block (Fig. 2a), one of four distinct tectonic blocks or micro-plates that make up the West Antarctic crust (Dalziel and Elliot, 1982). The other tectonic blocks include the Antarctic Peninsula, Thurston Island and Marie Byrd Land (Fig. 2a). To the north of the IMIS, the Filchner-Ronne Ice Shelf is underlain by the Weddell Sea Embayment, which separates the Antarctic Peninsula and Ellsworth-Whitmore Mountains blocks from the more tectonically stable East Antarctic Craton (Studinger and Miller, 1999). The Weddell Sea Embayment lies in a key position between West and East Antarctica 

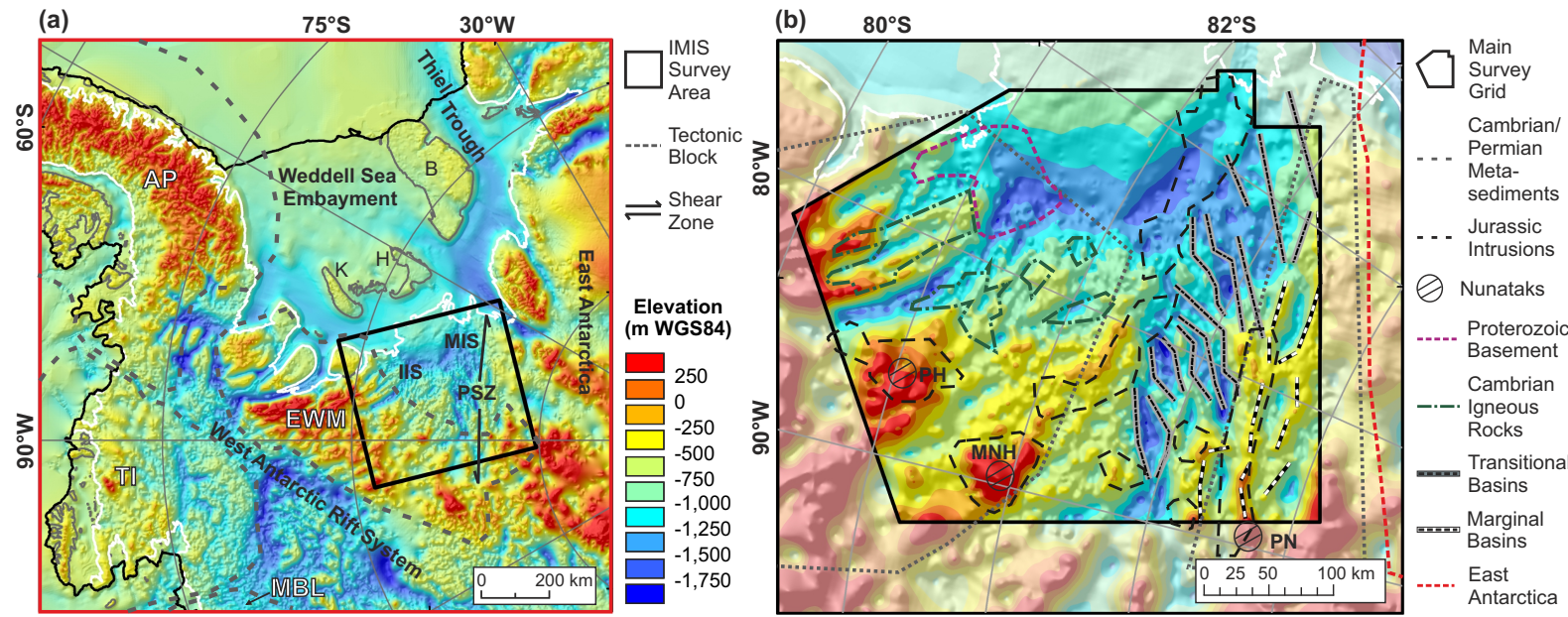

Figure 2. (a) Subglacial topography (Fretwell et al., 2013) overlain by the main tectonic features (Jordan et al., 2013) inferred for the Weddell Sea sector, West Antarctica. (b) Subglacial topography of the Institute and Möller ice streams overlain by inferred geological features and sediments. The lines denoting the Transitional and Marginal Basins mark their structural boundaries. The line between West and East Antarctica is inferred (Jordan et al., 2013). Annotations: AP - Antarctic Peninsula block; B - Berkner Island; EWM - EllsworthWhitmore Mountains block; H - Henry Ice Rise; K - Korff Ice Rise; MBL - Marie Byrd Land block; MIS - Möller Ice Stream; MNH Martin-Nash Hills; PH - Pirrit Hills; PN - Pagano Nunatak; PSZ - Pagano Shear Zone; TI - Thurston Island block.

in the region where Gondwana break-up initiated $\sim 180 \mathrm{Myr}$ ago (Storey et al., 2001; Dalziel et al., 2013). It is characterised by a region of thinned crust which extends $\sim 1200 \mathrm{~km}$ south from the foot of the continental slope to the EllsworthWhitmore Mountains block (Studinger and Miller, 1999; Jordan et al., 2013). In addition, a major strike-slip boundary (the Pagano Shear Zone) is inferred between the southeastern edge of the Ellsworth-Whitmore Mountains block and East Antarctica, in the region of the Transitional and Marginal Basins (Fig. 2). This boundary parallels (and likely dictates) the eastern shear margin of the MIS, and may extend along the Thiel Trough, defining the south-eastern edge of the Weddell Sea Embayment (Jordan et al., 2013). The timing of movement along the Pagano Shear Zone is uncertain, but plate reconstructions based on palaeomagnetic data suggest that the Ellsworth-Whitmore Mountains block reached its current position, relative to the Antarctic Peninsula and East Antarctica, by $\sim 175 \mathrm{Ma}$ (Dalziel et al., 2013).

Geological and geophysical surveys suggest that the bedrock underlying the IMIS is predominantly folded Palaeozoic metasediments and volcanic rocks (512-250 Ma), overlying more deeply buried Mesoproterozoic basement (> 1000 Ma) (Garrett et al., 1987; Storey and Dalziel, 1987; Curtis, 2001; Jordan et al., 2013) (Fig. 2b). The Palaeozoic bedrock has a dominant NW-SE structural trend, approximately parallel to the Ellsworth Mountains and adjacent Ellsworth Trough (Storey and Dalziel, 1987; Jordan et al., 2013), which developed during the $\sim 250 \mathrm{Ma}$ Gondwanide orogeny (Curtis, 2001). Several large Jurassic ( 175 Ma) granite intrusions crosscut older sediments forming isolated nunataks, such as the Pirrit Hills and the Martin-Nash Hills
(Fig. 2b), which protrude above the ice surface within the IMIS catchment (Storey et al., 1988). Geophysical data show the subglacial extent and shape of these intrusions. The Pirrit and Martin-Nash hills, for example, appear roughly circular in shape, whilst other structurally controlled intrusions that flank the Transitional Basins and underlying Pagano Shear Zone are more linear in form (Fig. 2b). The latter runs at an approximately $30^{\circ}$ angle to the structural trend of the Palaeozoic metasediments (Garrett et al., 1988; Jordan et al., 2013). In this region, the Pagano intrusion also forms the northern flank of the elongate Marginal Basins (Fig. 2b), which lie at the boundary between West and East Antarctica at the edge of the IMIS survey area (Jordan et al., 2013).

\section{Approach}

\subsection{Data collection}

In the austral summer of 2010/2011 an airborne geophysical survey was carried out across the IMIS. A central survey grid, with flight line spacing of $7.5 \mathrm{~km}$ and tie lines of $25 \mathrm{~km}$, was established over the ice streams, covering an area of $\sim 350 \times 400 \mathrm{~km}$ (Fig. 1a, light-grey gridded lines). Additional exploratory lines, with $50 \mathrm{~km}$ spacing, were also flown to link with previous regional surveys (Ross et al., 2012). Approximately 25000 line kilometres of radio-echo sounding (RES), gravity and magnetic data were collected (Jordan et al., 2013). Here, we discuss only the RES data. These were acquired using a coherent system with a $12 \mathrm{MHz}$ bandwidth and $150 \mathrm{MHz}$ carrier frequency (Corr et al., 2007), providing an approximate $10 \mathrm{~m}$ along-track sampling interval. Differential GPS, with a horizontal accuracy of $\sim 5 \mathrm{~cm}$, was 
used for positioning. Doppler processing was applied to migrate radar-scattering hyperbolae in the along-track direction (Hélière et al., 2007). The seismic processing software PROMAX was then used to carry out a semi-automated picking sequence that identifies the onset of the received bed echo.

Ice thickness was determined from the two-way travel time of the bed pick using a velocity of $0.168 \mathrm{~m} \mathrm{~ns}^{-1}$ coupled with a firn layer correction of $10 \mathrm{~m}$ (Ross et al., 2012). Bed elevations were then calculated by subtracting ice thickness measurements from ice surface elevations. The latter were determined from measurements of terrain clearance derived from radar/laser altimeter measurements, relative to the WGS84 ellipsoid. Cross-over rms errors are $\sim 18 \mathrm{~m}$ (Ross et al., 2012). These data have since contributed to the Bedmap2 depiction of Antarctic subglacial bed elevation (Fretwell et al., 2013).

\subsection{DEM, radar echograms and satellite imagery}

A digital elevation model (DEM) of subglacial topography was produced by rendering RES-derived bed elevations onto a $1 \mathrm{~km}$ grid mesh, using the "Topo to Raster" iterative finite difference interpolation function in ArcGIS. This algorithm employs a nested grid strategy to calculate successively finer grids until the user-specified resolution is obtained (Hutchinson, 1988, 1989), and it has been shown to be particularly effective in rendering glacial terrain (Fretwell et al., 2013). In addition, an isostatic correction was applied to the DEM to account for the removal of the modern ice sheet load. This comprised a simple Airy-type compensation, with an ice density of $915 \mathrm{~kg} \mathrm{~m}^{-3}$ and a mantle density of $3330 \mathrm{~kg} \mathrm{~m}^{-3}$. Whilst we acknowledge that this approach does not take into account the full complexity associated with glacio-tectonic interactions, it does provide a general indication of pre-glacial elevations across the region, offering insight into the landscape setting prior to glaciation. Radar echograms were also studied in order to assess detailed (along-track) basal topography and englacial structure. These images offer an immediate regional-scale perspective on the nature of the sub-ice landscape and add specific context to the DEM. Furthermore, the Moderate Resolution Imaging Spectroradiometer (MODIS) Mosaic of Antarctica (MOA) (Haran et al., 2005, updated 2013) was used to understand the morphology of the ice sheet surface (Scambos et al., 2007), as this can provide detailed insight into the nature of the underlying subglacial terrain (Ross et al., 2014).

\subsection{Geomorphometry}

The DEM was analysed in order to identify, map and quantify subglacial morphology and the spatial variability of geomorphic features. In particular, bed slope and hypsometry (area-elevation distribution) were quantified, as outlined below. Geomorphic features were also compared with maps of spectral bed roughness, derived from the IMIS survey radar transects (from Rippin et al., 2014). From the DEM, bed slope represents the gradient (rate of maximum change in $z$ value) from each grid cell to its neighbours and is measured in degrees (Burrough and McDonell, 1998). Abrupt changes in slope can reveal distinct changes in landscapes and specific topographic features, as well as providing an overview of general surface texture.

Hypsometric analysis quantifies the distribution of land surface area with altitude (Strahler, 1952). It is commonly used to understand the relationship between local and regional tectonics and the spatial variability in fluvial and glacial surface processes (Montgomery et al., 2001; Pedersen et al., 2010). Hypsometry identifies the dominant signal of landscape erosion, but is generally scale-dependent (Brocklehurst and Whipple, 2004). In order to assess hypsometry, therefore, the topographic drainage basin encompassing the IMIS was delineated. While this represents an artificial drainage divide boundary, as topography is predominantly below sea level within the survey area, it is a welldefined region that reflects the upslope area that contributes flow (normally water) to a common outlet (topographic low point along the basin boundary). Although it does not necessarily relate to a viable hydrological system (because rivers grade to sea level), the drainage region provides a discrete scale at which to calculate hypsometry (i.e. at basin scale).

Basal roughness is a measure of vertical variation with horizontal distance (e.g. Taylor et al., 2004; Li et al., 2010; Rippin et al., 2011). Low roughness records little vertical variation with horizontal distance, resulting in a surface with a smooth texture, whilst high roughness reflects significant vertical variation with horizontal distance, resulting in a surface with a rough texture. As the nature of basal topography exerts a control on ice flow, quantifying roughness at the ice-bed interface can be used to make inferences about ice-dynamic regimes (Hubbard et al., 2000; Siegert et al., 2005; Bingham et al., 2007; Bingham and Siegert, 2007, 2009). Previously, "smooth" (low-roughness) regions have been associated with fast-flowing ice, the presence of glacial sediments and/or significant glacial landscape modification, whilst "rough" topography is often associated with slowflowing ice and minimal glacial modification (Bingham and Siegert, 2007). Rippin et al. (2014) used a two-parameter fast Fourier transform to determine total roughness and the standard deviation of along-track bed topography to assess roughness directionality across the IMIS. Total basal roughness represents the amplitude (vertical irregularity) of bed roughness at all wavelengths and can perhaps be viewed as the "net" roughness determined for a given location. Directional roughness takes into account erosion relative to the ice-flow field by determining roughness variations both orthogonal and parallel to ice flow (Rippin et al., 2014; see detailed methods therein). Directional roughness may therefore highlight regions where substantial erosion parallel to ice flow has resulted in the formation of streamlined landforms, such as mega-scale glacial lineations (e.g. Graham et 


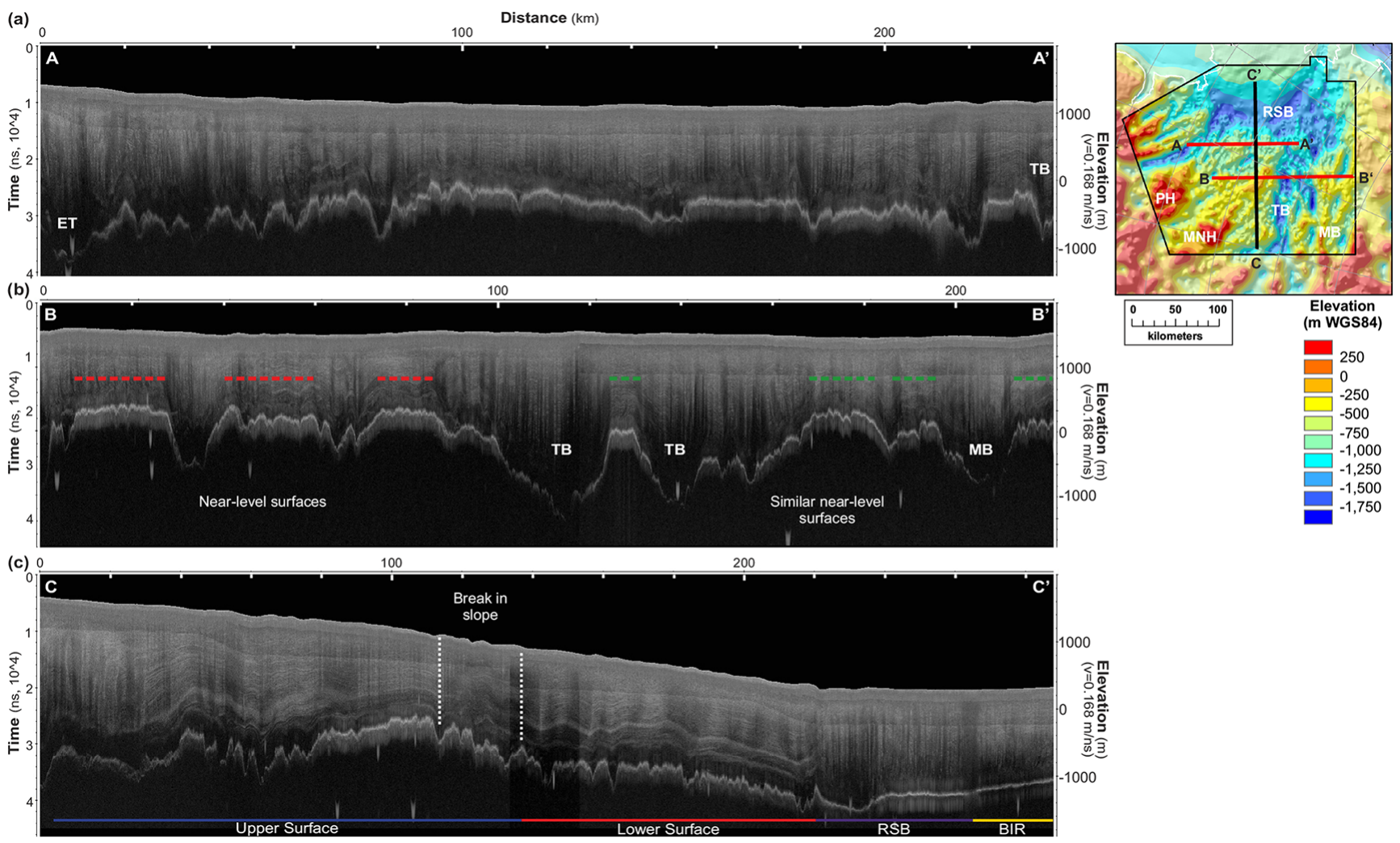

Figure 3. Radar echograms showing the gently sloping surfaces identified in subglacial topography. Inset shows the location of transects overlain on subglacial topography. (a) Cross-profile transect A-A', located proximal to the Robin Subglacial Basin, between the main tributaries of the Institute Ice Stream. (b) Cross-profile transect B-B', located further inland, extending between the Pirrit Hills (panel left) and the Marginal Basins (panel right), crossing the easternmost tributary of the Institute Ice Stream, which is underlain by the Transitional Basins. Cross-profiles show ice flow going into the page. Dashed lines (red and green) highlight regions of consistent summit elevation. (c) Long-profile transect C-C', running from the inland edge of the survey grid (panel left) to southern edge of the Bungenstock Ice Rise (panel right). Ice flow is roughly from left to right, but changes orientation across the Robin Subglacial Basin. Elevations are relative; topography in all transects is located below sea level (see inset). Annotations: BIR - Bungenstock Ice Rise; ET - Ellsworth Trough; MB Marginal Basin; MNH - Martin-Nash Hills; PH - Pirrit Hills; RSB - Robin Subglacial Basin; TB - Transitional Basins.

al., 2007; King et al., 2009). Here, we further develop the study by Rippin et al. (2014) by comparing regional-scale roughness characteristics and landscape geometry.

\section{Results}

\subsection{Subglacial topography}

\subsubsection{Radar echograms}

Figure 3 displays a series of radar echograms representing two cross-profiles and a single long-profile across the central IMIS survey area. The cross-profile radar echograms illustrate a smooth, gently sloping bed in the region between the Robin Subglacial Basin and the Pirrit and Martin-Nash hills (Fig. 3a and b). Proximal to the Robin Subglacial Basin, the lateral extent of this smooth bed is truncated on either side by the Ellsworth Trough and Transitional Basins (Fig. 3a). Further inland, the smooth bed is still evident but is less ob- viously continuous, being dissected by a number of typically U-shaped valleys (Fig. 3b, red dashed lines; lines show regions of summit elevation consistency). This radar echogram also shows evidence of similar (but more dissected) nearlevel surfaces in the region of the Marginal Basins, east of the Transitional Basins (Fig. 3b, green dashed lines). The longprofile radar echogram (Fig. 3c) shows that the surface is divided into two discrete topographic elements, which form a lower and an upper surface. These are separated by two pronounced breaks in slope, approximately 80 and $110 \mathrm{~km}$ inland from the edge of the Robin Subglacial Basin (Fig. 3c, vertical white dashed lines). The lower surface appears to dip towards the Robin Subglacial Basin, whilst the upper surface shows a distinct tilt inland.

\subsubsection{DEM}

The DEM shows the full extent of the surfaces identified in the radar echograms, revealing a smooth, gently slop- 

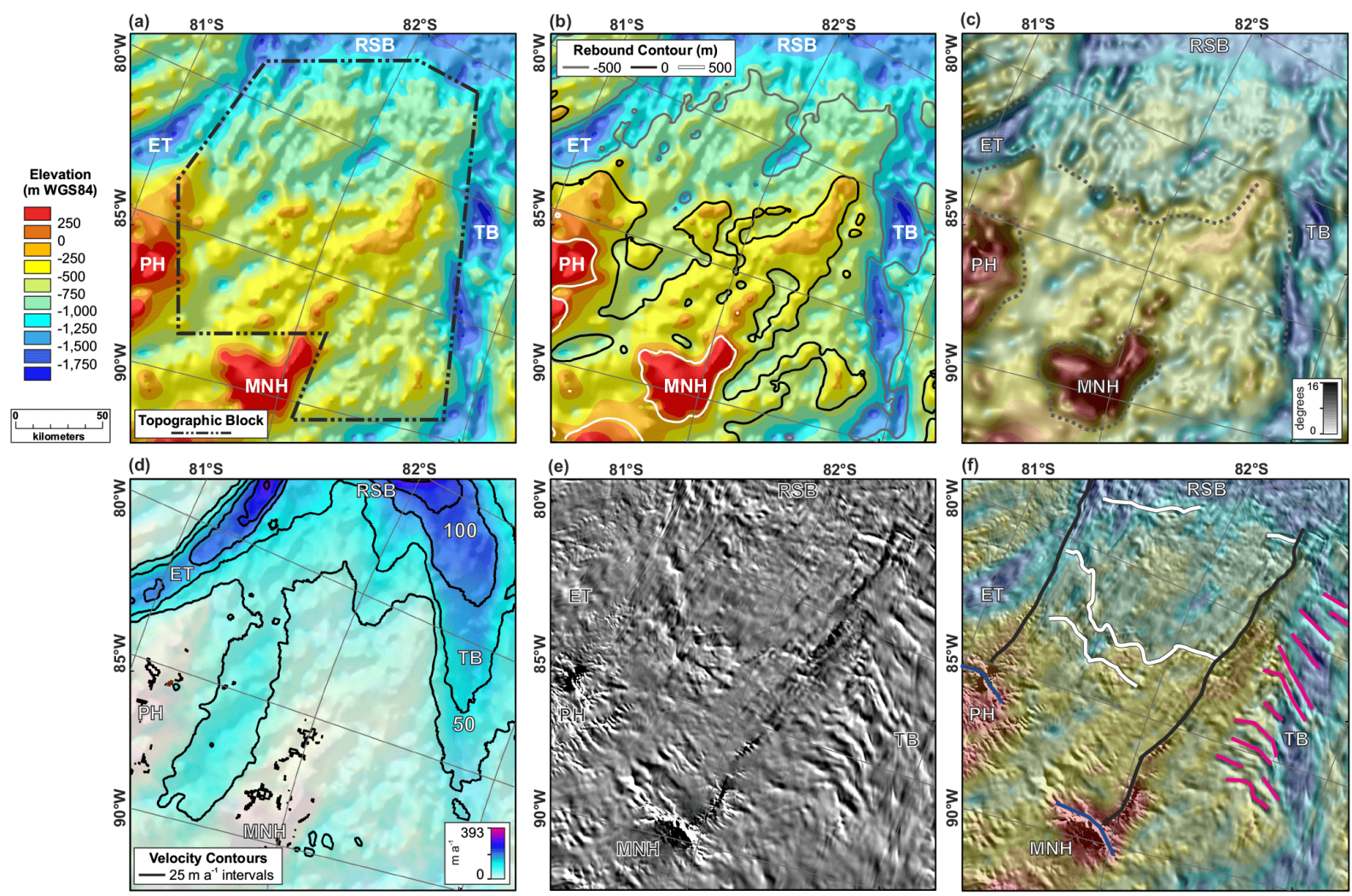

Figure 4. (a) Subglacial topography between the main Institute Ice Stream tributaries. Colour and distance scales for subglacial topography remain consistent for each panel. (b) Present-day bed elevations overlain with elevation contours (500 m intervals) derived from the isostatically adjusted topography. (c) Surface slope (semi-transparent) overlain on subglacial topography. Grey dotted lines mark regions of steep slopes $\left(>7^{\circ}\right.$ ). (d) Ice sheet surface velocity (semi-transparent) and velocity contours (Rignot et al., 2011) overlain on subglacial topography. (e) MODIS MOA imagery of the ice sheet surface. (f) MODIS MOA imagery (semi-transparent) overlain on subglacial topography and annotated to show the dominant morphological features observed (see Sect. 4.2). Extent of panels shown by rectangular dashed black box in Fig. 1b. Annotations: ET - Ellsworth Trough; MNH - Martin-Nash Hills; PH - Pirrit Hills; RSB - Robin Subglacial Basin; TB - Transitional Basins.

ing, roughly rectangular topographic block, located in the region between the Robin Subglacial Basin and the Pirrit and Martin-Nash hills (Fig. 1b, dashed black box, and Fig. 4a, black dot-dash line). The main block is $\sim 200 \times 150 \mathrm{~km}$ in size and is located between the Ellsworth Trough and the Transitional Basins. Slope analysis highlights five geomorphic features in the topography (Fig. 4c). First, steep slopes $\left(>7^{\circ}\right)$ are associated with the flanks of the Pirrit and MartinNash hills. They are also found at the lateral boundaries of the block, along the margins of the Ellsworth Trough and Transitional Basins. Second, these troughs and basins are characterised by steep-sided valley sides and flat-bottomed floors, indicative of U-shaped cross-profiles. Third, the block itself has generally low slope gradients $\left(<4^{\circ}\right)$, reflecting a gently dipping surface profile. Fourth, the middle of the block is dissected by a linear zone of higher slope values $\left(6-8^{\circ}\right)$, transverse to ice flow, which divides it into two sections (Fig. 4c). This break in slope is in keeping with observations from radar echograms at the ice surface and bed (Fig. 3c), and we note that it is also visible in DEMs of the ice sheet surface (e.g. Bamber et al., 2009; Fretwell et al., 2013). Fifth, under present-day ice cover, the elevation of the topographic block is predominantly below sea level (within a range of 200 to $-1500 \mathrm{~m}$, mean of $-656 \mathrm{~m}$ ). When a generalised isostatic correction is applied (Fig. 4b, contours), the elevation of the block rises (within a range of 600 to $-1100 \mathrm{~m}$ ), but mean elevation remains below sea level (mean of approximately $-270 \mathrm{~m})$. It is also noted that the estimated sea-level contour $(0 \mathrm{~m})$ (Fig. $4 \mathrm{~b})$ corresponds to the break in slope $(\sim 80 \mathrm{~km}$ from the Robin Subglacial Basin) identified across the centre of the block (Fig. 3c, white dashed line, and Fig. 4c).

\subsubsection{Hypsometry}

The hypsometry of the IMIS drainage basin (Fig. 5) displays two area-elevation maxima that are skewed downward $\left(H_{\max }\right.$ values of -900 and $-400 \mathrm{~m}$ ), demonstrating that the majority of the basin lies below sea level (within a range of 1591 to $-1971 \mathrm{~m}$, mean of $-643 \mathrm{~m}$; Fig. $5 \mathrm{~b}$ ). The style of 
(a)
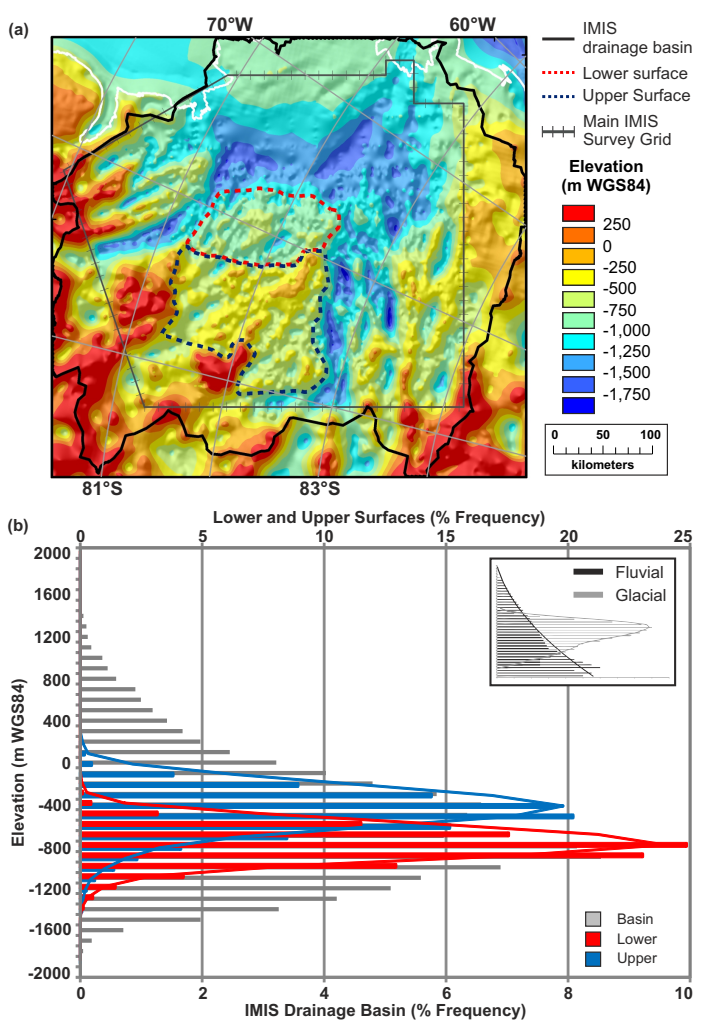

Figure 5. (a) Drainage basin determined for subglacial topography in the region of the Institute and Möller ice streams (IMIS). (b) Hypsometry (area-elevation distribution) determined for the IMIS drainage basin, in comparison with the lower (red) and upper (blue) erosion surfaces. The inset shows characteristic hypsometric distributions for fluvial (black) and glacial (grey) landscapes (Egholm et al., 2009).

hypsometry is consistent with glacial, rather than fluvial, environments (Egholm et al., 2009; Fig. 5b, inset). The areaelevation distribution of the gently sloping topographic block (Fig. 4a, black dot-dash line) was also determined in order to assess its setting within the context of the IMIS basin hypsometry (Fig. 5a). Because the radar data (Fig. 3c), in conjunction with slope analyses (Fig. 4c), reveal the block is divided into two surfaces, its hypsometry was also sub-divided into a lower surface proximal to the Robin Subglacial Basin (Fig. 5a, red dashed line) and an upper surface located further inland (Fig. 5a, blue dashed line).

The hypsometric distributions of the two surfaces fall within the central elevation range of the IMIS drainage basin bed (within a range of -100 to $-1100 \mathrm{~m}$ ) (Fig. 5b). Both the lower and upper surfaces show hypsometric maxima that are in line with the lower and upper $H_{\max }$ peaks recorded in the IMIS basin (lower $H_{\max }=-800 \mathrm{~m}$, upper $H_{\max }=-500 \mathrm{~m}$; Fig. 5b). This highlights that the majority (almost $60 \%$ ) of the drainage basin corresponds to the gently sloping block. The two surfaces that comprise the block lie almost completely below sea level $(<1 \%$ area above $0 \mathrm{~m})$, in keeping with their broad sea embayment setting. For each surface, a large proportion of the area lies within an elevation range of $200 \mathrm{~m}$, highlighting the low relief of this block. Specifically, $50 \%$ of the lower surface area lies between elevations of -800 and $-1000 \mathrm{~m}$ and $40 \%$ of the upper surface area lies between elevations of -400 and $-600 \mathrm{~m}$.

\subsubsection{Roughness}

A thorough analysis of spectral basal roughness across the IMIS was carried out by Rippin et al. (2014). Here, we discuss the total basal roughness and roughness directionality derived from that work (Fig. 6), and its relation to the morphological analyses presented above. Generally the block is characterised by low roughness $(\leq 0.1)$ at all wavelengths (total roughness) (Fig. 6b). A band of slightly higher total roughness $(0.1-0.2)$ is also evident in the centre of this region, corresponding with the break in slope in the topography (Figs. 3c and 4c). Low total roughness values are also found across the sediment-filled Robin Subglacial Basin and the Bungenstock Ice Rise. Higher total roughness values $(>0.2)$ are typically associated with the surrounding Ellsworth Mountains and Pirrit and Martin-Nash hills (Fig. 6b). Similarly, when examining the directionality of roughness relative to present-day ice flow, the lowest values are associated with the Robin Subglacial Basin and Bungenstock Ice Rise, whilst the highest values generally correlate with subglacial mountains. In other regions, such as the Transitional Basins, we find that roughness orthogonal to flow is typically higher than that parallel to flow (Fig. 6c and d). In contrast, however, the block shows a different pattern, whereby roughness is lower (0.24) orthogonal to ice flow (Fig. 6c) but higher (0.35) parallel to flow (Fig. 6d). These patterns reveal that the block has generally low basal roughness, dominated by shorter wavelength variations (typically parallel to ice flow), which gives it a distinct roughness character within the IMIS basin (Rippin et al., 2014). Similarly, the Robin Subglacial Basin is also defined by its own distinct (extremely smooth) roughness character that is particularly evident in the patterns of roughness directionality (Fig. 6c and d).

\subsection{Ice sheet surface imagery}

MODIS MOA imagery highlights four key morphological features in the ice sheet surface that reflect distinct changes in the nature (e.g. roughness, elevation) of the underlying subglacial topography (Fig. 4e). First, the isolated granite intrusions of the Pirrit and Martin-Nash hills are characterised by a rough surface texture (Fig. 4f, blue lines), forming clustered "corrugated" features, orientated transverse to ice flow. Second, downstream of each hill is a linear feature, aligned with ice flow in the direction of the grounding line (Fig. 4f, black lines). Third, located between these are a series of linear to curved features that lie transverse to ice flow (Fig. 4f, white 

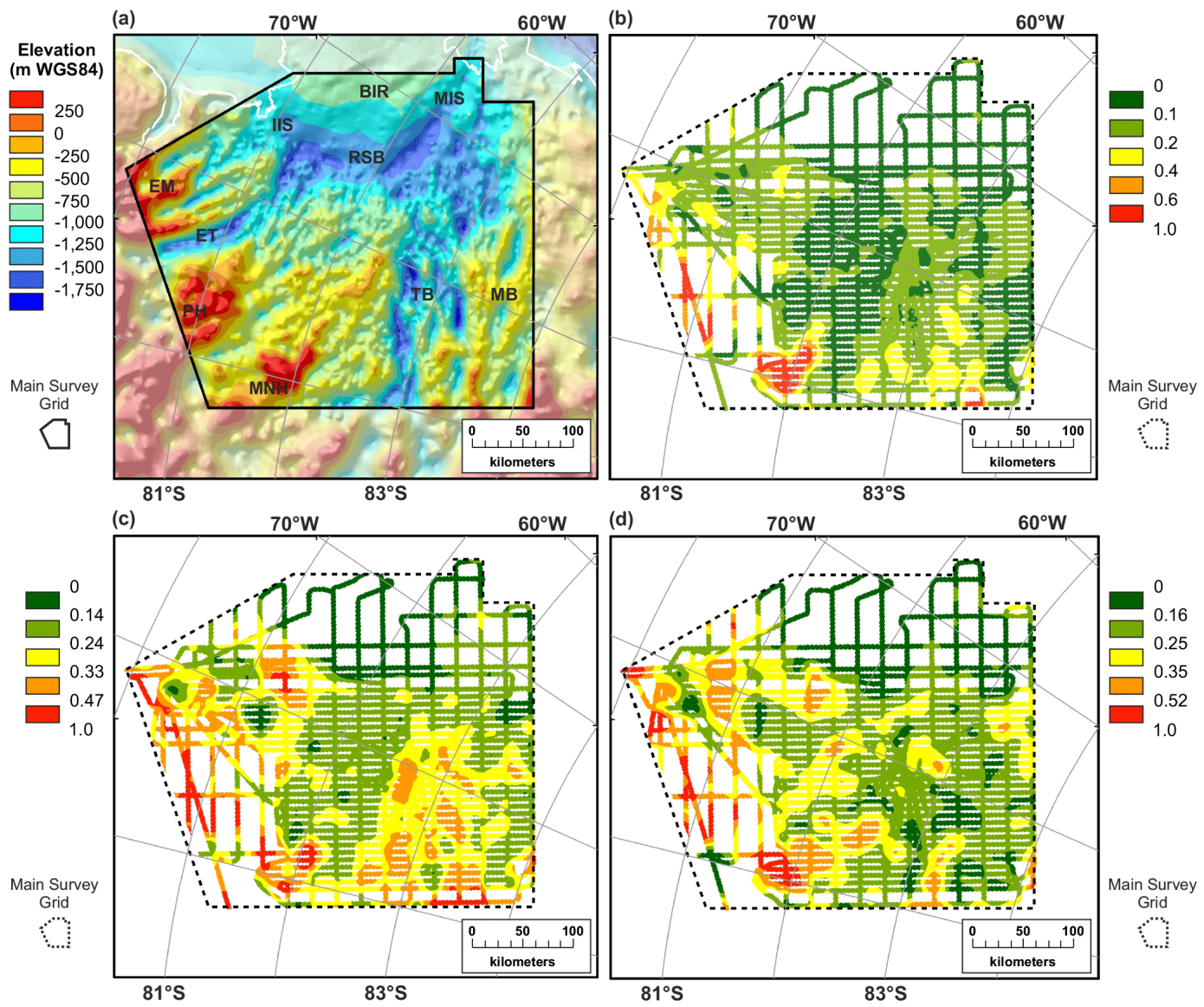

Figure 6. (a) Subglacial topography of the Institute and Möller ice streams overlain on semi-transparent Bedmap2 topography. Annotations: BIR - Bungenstock Ice Rise; EM - Ellsworth Mountains; ET - Ellsworth Trough; IIS - Institute Ice Stream; MB - Marginal Basins; MIS - Möller Ice Stream; MNH - Martin-Nash Hills; PH - Pirrit Hills; RSB - Robin Subglacial Basin; TB - Transitional Basins. (b) Total basal roughness determined from bed elevation data along IMIS survey flight lines. (c) Basal roughness determined using the standard deviation of along-track bed topography orthogonal to ice flow. (d) Basal roughness determined using the standard deviation of along-track bed topography parallel to ice to flow. Adapted from Rippin et al. (2014).

lines). The most distinct and laterally continuous curved surface feature runs across the middle of this region. These features, respectively, correspond to the lateral boundaries of the block and the break in slope identified $(80 \mathrm{~km}$ inland from the Robin Subglacial Basin) in radar echograms (Fig. 3c) and the DEM (Fig. 4c). Fourth, we also note a series of surface features perpendicular to ice flow in the region of the most easterly main tributary of the IIS (Fig. 4f, pink lines). These are clearly associated with ice flow across the basal topography of the Transitional Basins.

\section{Interpretation}

\subsection{Erosion surfaces}

Geomorphic analyses of the DEM and supporting evidence from radar echograms and satellite imagery have enabled us to identify a gently sloping, low-relief topographic block, with associated low basal roughness, in the region between the Robin Subglacial Basin and the Pirrit and Martin-Nash hills, located further inland. We interpret this region as two large-scale erosion surfaces separated by a marked break in slope (Fig. 3c, white dashed line).

We consider that these surfaces represent erosional rather than depositional topographic features for three reasons. First, they are located inland of the grounding line where the movement of grounded ice and subglacial water is more likely to result in erosion. In particular, in the past (e.g. the LGM), when the ice sheet margin was located at the continental shelf, the erosion surfaces would have been located even further into the ice sheet interior, demonstrating that this is not an obvious position for major glacial-sedimentary deposition. Second, landscape relief points to the region having been subject to erosional processes (Fig. 1). For example, Jurassic granites that comprise the Pirrit and MartinNash hills, which protrude above the present-day ice sheet surface, were emplaced between $\sim 175$ and $165 \mathrm{Ma}$ (Storey et al., 1988; Lee et al., 2012) and have since been exposed 
by erosion. The relief today between the mountain peaks and the upper erosion surface demonstrates that a significant amount of rock (at least $2 \mathrm{~km}$ ) has been removed since the Jurassic. Furthermore, the presence of troughs and basins below sea level, particularly the Ellsworth Trough, indicates significant removal of material by glacial processes. Third, radar echograms show that the gently sloping erosion surfaces display small-scale undulations and intermittent valleys (Fig. 3a), giving this region a different (shortwavelength) roughness (Fig. 6a) that distinguishes it from the likely sediment-filled Robin Subglacial Basin (Rippin et al., 2014). Although we cannot rule out that there may be pockets of sediments or even a thin sedimentary drape in places across the surface, there is no evidence from radar or gravity data for a saturated or thick sedimentary deposit in this region. The surfaces are, therefore, more in keeping with an extensive erosional bedrock landscape setting.

\subsection{Preservation}

Glaciological conditions now and in the past (i.e. since ice sheet glaciation of West Antarctica) are conducive to landscape preservation between the IIS tributaries. MODIS MOA imagery reveals two linear surface features in the lee of the Pirrit and Martin-Nash hills (Fig. 4e and f), which correspond to the lateral boundaries of the block (Fig. 4a). Clearly, these mountains significantly modulate regional ice flow, reducing ice velocities immediately downstream and focusing flow along the adjacent troughs and basins that now host the fast-flowing ( $>50 \mathrm{~m} \mathrm{a}^{-1}$ ) tributaries of the IIS (Fig. 4d).

The region was also unlikely to have been a fast flow zone during full glacial conditions during the Quaternary, as there would be slow, interior ice-sheet-type flow (i.e. by internal ice deformation only) across this region when ice was at the shelf edge. In addition, the erosion surfaces display their own distinct roughness signal, with comparatively high values parallel to ice flow, versus those orthogonal to flow (Fig. 6c and d). This indicates that the landscape has not experienced significant streamlining by ice but rather retains a signal of pre-glacial geomorphic processes (Rippin et al., 2014).

\subsection{Selective glacial erosion}

Radar echograms reveal that the block has been subject to a degree of selective glacial erosion following formation. A few valleys (often U-shaped) are visible in cross-profile A, particularly in proximity to the Ellsworth Trough (Fig. 3a), whilst further inland cross-profile $\mathrm{B}$ has been more significantly dissected by broader U-shaped valleys (Fig. 3b). The scale and style of these intermittent, U-shaped valleys are suggestive of selective linear erosion by small- to regionalscale, warm-based ice masses (Sugden and John, 1976; Hirano and Aniya, 1988). Given the broad preservation of the topographic block, the ice sheet likely comprised polyther- mal basal conditions, with spatially restricted zones of warmbased ice focused along valleys to form deep troughs, and cold-based ice associated with low erosion rates located in the lee of the Jurassic intrusions. The locations of the valleys are likely to reflect lines of structural tectonic weaknesses (Jordan et al., 2013) or pre-existing fluvial networks that have been exploited (e.g. Baroni et al., 2005; Rose et al., 2013; Ross et al., 2014).

We propose that incision of the erosion surfaces occurred during periods of intermediate ice sheet cover (cf. Young et al., 2011) when corridors of warm-based ice, subject to topographic steering, flowed around the Pirrit and Martin-Nash hills. Ross et al. (2012) use the location of troughs and elevated bars to infer the position of a former grounding line upstream of the Robin Subglacial Basin. Their findings indicate that, even under a smaller-scale, restricted ice sheet configuration, the majority of ice drainage would likely follow the linear topographic valleys that flank this block (cf. Rose et al., 2014). This would minimise the degree of glacial incision between the valleys (i.e. where there may have been coldbased ice), helping to retain pre-glacial landscape signals across the erosion surfaces. Subsequently, once the ice sheet expanded to a continental scale, buttressing of ice sheet flow by the Pirrit and Martin-Nash hills would also restrict extensive landscape modification by glacial erosion downstream of these major mountain massifs. The existence of an extensive, although incised, erosion surface demonstrates that it is possible to preserve ancient surfaces beneath an ice sheet at low elevations, and not just at high elevations associated with thin, cold-based ice (Rose et al., 2013; Ross et al., 2014). It is also interesting to note that whilst regions of smooth and flat topography are typically associated with relatively fast ice flow and often inferred marine sediments (Joughin et al., 2006; Peters et al., 2006; Bingham and Siegert, 2007), we do not find that relationship here. Instead, the fastest ice flow exploits the deeply incised troughs and basins that flank the low-roughness erosion surfaces.

\subsection{Regional extent}

We also find additional evidence indicating that the surfaces may have been more extensive in the past. Radar echograms, for example, hint at the existence of a more laterally continuous erosion surface extending across to the Transitional and Marginal Basins (Fig. 3b, green dashed lines). This is indicated by the presence of a few, isolated, flat-topped hills between the basins (Figs. $1 \mathrm{~b}$ and $3 \mathrm{~b}$ ). These basins are tectonically controlled (Jordan et al., 2013), and it is likely that they developed (overdeepened) due to glacial erosion (down-cutting) exploiting these pre-existing tectonic structures. Low roughness values parallel to ice flow highlight that glacial erosion has been particularly effective along these basins (Fig. 6d). As a result, only remnants of this surface, between basins, have remained (Burbank and Anderson, 2012). Without such structural controls driving erosion 
in these locations, a greater proportion and a more continuous surface may have been retained. These smaller, localised remnants of the erosion surface are harder to identify from the DEM (because it is derived from an aerogeophysical survey with a line spacing of $7.5 \mathrm{~km}$ ), but their existence is reflected in the cumulative proportion of area-elevation shown in the hypsometry. We find that $60 \%$ of area-elevation distribution in the IMIS drainage basin corresponds to the elevations of the block, but the block only accounts for $15 \%$ of the area of the IMIS drainage basin (Fig. 5b). This gives support to the idea that the ancient erosion surface once occupied a much larger proportion of the embayment but that it has since been dissected by glacial (and likely other) erosion processes.

Indeed, if we examine the landscape at a regional scale, it is easy to see how a larger-scale, more continuous erosion surface may have existed across the Weddell Sea Embayment in the past. In particular, Berkner Island and the Henry and Korff ice rises stand out as regions of gently dipping, smooth topography now encompassed by the Filchner-Ronne Ice Shelf (Fig. 1a). Closer to the present-day grounding line, the Skytrain Ice Rise, Fletcher Promontory and Fowler Peninsula also provide evidence for low-gradient, low-relief surfaces (Doake et al., 1983). The geometry of these features is comparable to the form of the topographic block we identify between the primary IIS tributaries. From this we may infer that, coupled with the block, they may once have formed part of a more continuous erosion surface that occupied a significant proportion of the embayment. If such a surface existed, then it also seems likely that the same dominant process(es) of landscape development acted at a regional scale across the Weddell Sea Embayment and not just at a local scale in the region of the block.

\section{Discussion}

We have mapped a distinct topographic block within the IMIS survey area and characterised it as two ancient preserved erosion surfaces. It is, however, much more difficult to attribute the mode of formation of the erosion surfaces to a particular mechanism. This is largely because the processes involved in the formation of geometrically flat bedrock surfaces are subject to long-standing debates and uncertainty. Globally, erosion surfaces have been described in a number of settings and, although it may not be possible to determine with certainty the exact origin of the erosion surfaces identified, here we briefly discuss a few of the settings and erosion regimes that are commonly associated with erosion surfaces cut into basement rocks.

We have two favoured models and associated processes responsible for the formation of the erosion surfaces: the first is marine erosion, the second fluvial erosion. Both are consistent with our evidence for a gently sloping, low-relief topo- graphic block characterised by a low surface roughness and an elevation near to isostatically rebounded sea level.

\subsection{Marine erosion model}

Marine erosion is concentrated at the interface between land and sea through the constant action of waves impacting a shoreline, often during a period of tectonic (and sea level) quiescence (Burbank and Anderson, 2012). A marine origin for large-scale erosion surfaces is possible and large-scale marine erosion surfaces are often linked with polar glacial environments. In the Northern Hemisphere, shore platforms, known as strandflats, are found along almost the whole west coast of Norway (Klemsdal, 1982), as well as in Greenland (Bonow et al., 2007), Alaska and Scotland (Dawson et al., 2013). These examples demonstrate that erosion surfaces often extend for many hundreds of kilometres (around coastlines) and may be tens of kilometres wide. They are thought to result primarily from marine abrasion, with contributions from subsequent weathering and glacial erosion processes (Fredin et al., 2013). In Norway, strandflats are found both above and below sea level. Typically, they lie in front of higher land or coastal mountains and form either level or gently dipping bedrock surfaces from the coast (Klemsdal, 1982; Fredin et al., 2013). We find some analogy between the Norwegian strandflats and the setting of the IMIS drainage basin, where the Ellsworth Subglacial Highlands and other mountains are found inland of the erosion surfaces (Fig. 1a), and a gentle coastal dip is evident in the lower surface (Fig. 3c).

In West Antarctica, a sequence of palaeo-erosion surfaces has also been identified in the Ross Sea sector, located between -100 and $-350 \mathrm{~m}$ (Wilson and Luyendyk, 2006a, b). These surfaces are laterally continuous, averaging the same elevation over large distances. They are $100 \mathrm{~s} \mathrm{~km}$ wide and discontinuous, separated by troughs that are occupied by the ice streams of the Siple Coast. Using additional evidence from gravity and marine seismic data sets, Wilson and Luyendyk (2006a, b) interpreted these surfaces as the remnants of a former, continuous wave-cut shore platform.

If we apply a marine erosion model for the erosion surfaces we identify beneath the IIS, we suggest that the surfaces were cut at, or just below, sea level by wave action prior to Antarctic glaciation or during periods when the ice sheet was significantly smaller than today. Such a model is consistent with the isostatically rebounded average elevation of the surface $(-270 \mathrm{~m})$, its geomorphic context (i.e. at the head of the Weddell Sea Embayment) and its proximity to the mountain ranges of the Ellsworth-Whitmore Mountains block, in a setting analogous to that of the strandflat features of the Arctic. Although we accept that the width of the erosion surfaces is unusually large $(\sim 150 \mathrm{~km}$ in total, $\sim 80 \mathrm{~km}$ lower surface, $\sim 70 \mathrm{~km}$ upper surface) for it to have been cut by processes of marine erosion alone, we note that the Norwegian strandflat is $60 \mathrm{~km}$ wide in places (Porter, 1989) and that many Antarctic glacial landforms (e.g. glacial troughs, cirques) are often 
considerably larger in scale than similar features elsewhere on Earth (Haynes, 1998; Young et al., 2011).

\subsection{Fluvial erosion model}

Fluvial erosion processes are also capable of generating large-scale, low-gradient bedrock surfaces. Rivers work to reduce surface elevations to a base level, typically at sea level, through the erosion, transportation and deposition of material (Burbank and Anderson, 2012). This often occurs in passive continental margin settings (Beaumont et al., 2000), where fluvial erosion cuts a new base level following rifting. This results in a coastal plain which is then backed by escarpments, the number of which depends on lithology and geological structure.

An alternative model for the formation of the erosion surfaces beneath the IIS, therefore, is that it was the result of fluvial peneplain erosion during, and after, the rifting and break-up of Gondwanaland around $\sim 180 \mathrm{Ma}$. A constraint on the maximum age of the surface is provided by the $175 \mathrm{Ma}$ granitic intrusions of the Pirrit and Martin-Nash hills, which demonstrate that the surface cannot be older than this. As a consequence of the rifting of Gondwanaland, fluvial systems on the passive margins of the rifts incised into the landscape in response to the subsequent downward shift in base level (Beaumont et al., 2000). This incisional phase resulted in the formation of the broad extensive coastal surfaces, backed by erosional escarpments and characterised by occasional inselbergs, mapped in southern Africa (e.g. Namibia) and South America (Brown et al., 2000). The same processes (i.e. fluvial erosional processes operating in a passive continental margin setting) may also have been responsible for the development of the surfaces we have identified. In the case of the Antarctic features, however, the surfaces were later incised and fragmented by tectonic processes (e.g. major strike-slip faulting) (Jordan et al., 2013) and by selective linear glacial erosion (Ross et al., 2012) (Fig. 3b). Despite the action of these surface processes, large parts of the ancient erosion surfaces remain little modified. They have been preserved by their situation in the interior of the ice sheet, where rates of subglacial erosion are low (Jamieson et al., 2010), and because of the long-term protection offered by the Pirrit and Martin-Nash hills, which have buttressed downstream ice, limiting glacial erosional capacity (see Sect. 5.2). Assuming the fluvial model to be correct, one interesting possibility is that the prominent break in slope that we identify (Figs. 3c and $4 \mathrm{c}, \mathrm{e}, \mathrm{f}$ ) may be analogous to the escarpments that back the coastal plains of southern Africa (Brown et al., 2000).

One line of evidence that could be seen as inconsistent with the fluvial model proposed is that the mean elevation of the isostatically rebounded surface is $-270 \mathrm{~m}$. However, given the potential age of the surfaces (i.e. they may have formed long before extensive ice-sheet glaciation in Antarctica), uncertainties over the tectonic structure and history of this area, and the simplicity of the calculation of the isostatic correction applied here, it may simply be that the isostatically rebounded elevation of the surface is unrepresentative of the elevation at which the surface originally formed. In the Transantarctic Mountains in East Antarctica, ancient relict surfaces are found at elevations far above present-day, or icefree, sea level conditions (Sugden et al., 1995; Kerr et al., 2000).

If the fluvial model is correct, however, it opens up the possibility of using detailed investigations of Antarctic subglacial topography to improve our understanding of the nature of Gondwanaland rifting and, from this, the formation of the Antarctic continent. We note that several studies (e.g. Sugden et al., 1995; Kerr et al., 2000; Näslund, 2001; Jamieson and Sugden, 2008) have also proposed the preservation of other ancient (e.g. Gondwanaland) surfaces in East Antarctica. It may be that the flat-lying surfaces identified elsewhere in the Weddell Sea sector of West Antarctica, as well as those in the Ross Sea, previously interpreted as wavecut shore platforms (Wilson and Ludendyk, 2006a, b), may also be remnants of extensive ancient fluvial surfaces.

\section{Conclusions}

A new DEM, built from an extensive and high-resolution modern airborne radar survey, provides a detailed view of subglacial topography across the IMIS, where previously only sparse data were available (Bingham and Siegert, 2007). We have examined radar echograms and MODIS MOA imagery and applied morphometric analyses to the DEM in order to characterise the landscape. In doing so, we have (1) identified a smooth, laterally continuous, gently sloping topographic block in the region between the Robin Subglacial Basin and the Pirrit and Martin-Nash hills; (2) characterised this block as two surfaces separated by a distinct break in slope; (3) shown that erosion rates across the surfaces are currently low, precluding formation via present-day glacial erosion; and (4) interpreted these features as erosion surfaces.

Our findings show that it is possible for ancient erosion surfaces to be preserved at low elevations beneath ice sheets. We have also identified the Pirrit and Martin-Nash hills as having played a key role in the long-term landscape evolution of this region. By buttressing upstream ice and reducing downstream ice velocities, they have limited glacial erosion rates in their lee, thus enabling long-term preservation of the erosion surfaces. By modulating ice dynamics, these mountain massifs have facilitated a region where smooth, low-geometry basal topography does not correspond to the fast ice flow typically associated with ice streams. Whilst we have characterised the topographic block, we have not been able to constrain the dominant mechanism of formation for the erosion surfaces based on the current data available. Instead, we have presented a number of different erosion regimes (namely fluvial and marine) that are associated 
with the formation of erosion surfaces in order to inspire further investigation in this region so that the origin of these surfaces may be deciphered with greater certainty in the future.

Acknowledgements. This project was funded by UK NERC AFI grant NE/G013071/1. Carl Robinson (Airborne Survey engineer), Ian Potten and Doug Cochrane (pilots), and Mark Oostlander (air mechanic) are thanked for their invaluable assistance in the field. We thank Arjen Stroeven and an anonymous reviewer for helpful comments on an earlier draft of this manuscript. We would also like to extend particular thanks to David Sugden, whose helpful, fruitful and generous discussions enabled us to improve the manuscript greatly.

Edited by: J. Willenbring

\section{References}

Bamber, J. L., Gomez-Dans, J. L., and Griggs, J. A.: A new 1 km digital elevation model of the Antarctic derived from combined satellite radar and laser data - Part 1: Data and methods, The Cryosphere, 3, 101-111, doi:10.5194/tc-3-101-2009, 2009.

Baroni, C., Noti, V., Ciccacci, S., Righini, G., and Salvatore, M.C.: Fluvial origin of the valley system in northern Victoria Land (Antarctica) from quantitative geomorphic analysis, Geol. Soc. Am. Bull., 117, 212-228, doi:10.1130/B25529.1, 2005.

Beaumont, C., Kooi, H., and Willett, S.: Coupled tectonic-surface process models with applications to rifted margins and collision orogens, in: Geomorphology and Global Tectonics, edited by: Summerfield, M. A., John Wiley \& Sons, Chichester, 29-55, 2000.

Bingham, R. G. and Siegert, M. J.: Radar-derived bed roughness characterization of Institute and Möller ice streams, West Antarctica, and comparison with Siple Coast ice, Geophys. Res. Lett., 34, L21504, doi:10.1029/2007g1031483, 2007.

Bingham, R. G., and Siegert, M. J.: Quantifying subglacial bed roughness in Antarctica: implications for ice-sheet dynamics and history, Quaternary Sci. Rev., 28, 223-236, 2009.

Bingham, R. G., Siegert, M. J., Young, D. A., and Blankenship, D. D.: Organized flow from the South Pole to the Filchner-Ronne ice shelf: An assessment of balance velocities in interior East Antarctica using radio echo sounding data, J. Geophys. Res.Earth, 112, F03S26, doi:10.1029/2006jf000556, 2007.

Bonow, J. M., Lidmar-Bergström, K., Japsen, P., Chalmers, J. A., and Green, P. F.: Elevated erosion surfaces in central West Greenland and southern Norway: their significance in integrated studies of passive margin development, Norweg. J. Geol., 87, 197206, 2007.

Brocklehurst, S. H. and Whipple, K. X.: Hypsometry of glaciated landscapes, Earth Surf. Proc. Land., 29, 907-926, 2004.

Brown, R. W., Gallagher, K., Gleadow, A. J. W., and Summerfield, M. A.: Morphotectonic evolution of the South Atlantic margins of Africa and South America, in: Geomorphology and Global Tectonics, edited by: Summerfield, M. A., John Wiley \& Sons, Chichester, 255-281, 2000.

Burbank, D. W. and Anderson, R. S.: Tectonic Geomorphology, 2nd Edn., Wiley-Blackwell, Chichester, UK, 2012.
Burrough, P. A. and McDonell, R. A.: Principles of Geographical Information Systems, Oxford University Press, New York, 1998.

Corr, H., Ferraccioli, F., Frearson, N., Jordan, T. A., Robinson, C., Armadillo, E., Caneva, G., Bozzo, E., and Tabacco, I. E.: Airborne radio-echo sounding of the Wilkes Subglacial Basin, the Transantarctic Mountains, and the Dome $\mathrm{C}$ region, in: The Italian-British Antarctic Geophysical and Geological Survey in Northern Victoria Land 2005-06 - Towards the International Polar Year 2007-08, edited by: Bozzo, E. and Ferraccioli, F., Terra Antartica Reports, Terra Antartica Publications, Siena, 13, 5563, 2007.

Curtis, M. L.: Tectonic history of the Ellsworth Mountains, West Antarctica: Reconciling a Gondwana enigma, Geol. Soc. Am. Bull., 113, 939-958, 2001.

Dalziel, I. W. D. and Elliot, D. H.: West Antarctica: problem child of Gondwanaland, Tectonics, 1, 3-19, 1982.

Dalziel, I. W. D., Lawver, L., Norton, I. O., and Gahagan, L. M.: The Scotia Arc: Genesis, Evolution, Global Significance, Annu. Rev. Earth Planet. Sci., 41, 767-793, 2013.

Dawson, A. G., Dawson, S., Cooper, A. G., Gemmell, A., and Bates, R.: A Pliocene age and origin for the strandflat of the Western Isles of Scotland: a speculative hypothesis, Geolog. Mag., 150, 360-366, 2013.

Doake, C. S. M., Crabtree, R. D., and Dalziel, I. W. D.: Subglacial Morphology between Ellsworth Mountains and Antarctica Peninsula: New Data and Tectonic Significance, Proceedings of the 4th International Symposium on Antarctic Earth Sciences, Cambridge University Press, New York, 270-273, 1983.

Egholm, D. L., Nielsen, S. B., Pedersen, V. K., and Lesemann, J. E.: Glacial effects limiting mountain height, Nature, 460, 884-888, 2009.

Fredin, O., Bergstrom, B., Eilertsen, R., Hansen, L., Longva, O., Nesje, A., and Sveian, H.: Glacial landforms and Quaternary landscape development in Norway, in: Quaternary Geology of Norway, edited by: Olsen, L., Fredin, O., and Olesen, O., Geological Survey of Norway Special Publication, Geological Survey of Norway, Trondheim, 5-25, 2013.

Fretwell, P., Pritchard, H. D., Vaughan, D. G., Bamber, J. L., Barrand, N. E., Bell, R., Bianchi, C., Bingham, R. G., Blankenship, D. D., Casassa, G., Catania, G., Callens, D., Conway, H., Cook, A. J., Corr, H. F. J., Damaske, D., Damm, V., Ferraccioli, F., Forsberg, R., Fujita, S., Gim, Y., Gogineni, P., Griggs, J. A., Hindmarsh, R. C. A., Holmlund, P., Holt, J. W., Jacobel, R. W., Jenkins, A., Jokat, W., Jordan, T., King, E. C., Kohler, J., Krabill, W., Riger-Kusk, M., Langley, K. A., Leitchenkov, G., Leuschen, C., Luyendyk, B. P., Matsuoka, K., Mouginot, J., Nitsche, F. O., Nogi, Y., Nost, O. A., Popov, S. V., Rignot, E., Rippin, D. M., Rivera, A., Roberts, J., Ross, N., Siegert, M. J., Smith, A. M., Steinhage, D., Studinger, M., Sun, B., Tinto, B. K., Welch, B. C., Wilson, D., Young, D. A., Xiangbin, C., and Zirizzotti, A.: Bedmap2: improved ice bed, surface and thickness datasets for Antarctica, The Cryosphere, 7, 375-393, doi:10.5194/tc-7-3752013, 2013.

Garrett, S. W., Herrod, L. D. B., and Mantripp, D. R.: Crustal structure of the area around Haag Nunataks, West Antarctica: new aeromagnetic and bedrock elevation data, in: Gondwana Six: Structure, Tectonics and Geophysics, edited by: McKenzie, G. D., AGU Geophysical Monograph, Washington, D.C., 109-116, 1987. 
Garrett, S. W., Maslanyj, M. P., and Damaske, D.: Interpretation of aeromagnetic data from the Ellsworth Mountains-Thiel Mountains ridge, West Antarctica, J. Geol. Soc. Lond., 145, 10091017, 1988.

Graham, A. G. C., Lonergan, L., and Stoker, M. S.: Evidence for Late Pleistocene ice stream activity in the Witch Ground Basin, central North Sea, from 3D seismic reflection data, Quaterny Sci. Rev., 26, 627-643, 2007.

Haran, T., Bohlander, J., Scambos, T., Painter, T., and Fahnestock, M.: MODIS Mosaic of Antarctica (MOA) Image Map, National Snow and Ice Data Centre, Boulder, Colorado, USA, 2005, updated, 2013

Haynes, V. M.: The morphological development of alpine valley heads in the Antarctic Peninsula, Earth Surf. Proc. Land., 23, 53-67, 1998.

Hélière, F., Lin, C. C., Corr, H., and Vaughan, D.: Radio echo sounding of Pine Island Glacier, West Antarctica: Aperture synthesis processing and analysis of feasibility from space, IEEE T. Geosci. Remote, 45, 2573-2582, 2007.

Hirano, M. and Aniya, M.: A rational explanation of cross-profile morphology for glacial valleys and of glacial valley development, Earth Surf. Proc. Land., 13, 707-716, 1988.

Hubbard, B. P., Siegert, M. J., and McCarroll, D.: Spectral roughness of glaciated bedrock geomorphic surfaces: Implications for glacier sliding, J. Geophys. Res., 105, 21295-21303, 2000.

Hutchinson, M. F.: Calculation of hydrologically sound digital elevation models, in: Third International Symposium on Spatial Data Handling, Columbus, Ohio, International Geographical Union, Sydney, 117-133, 1988.

Hutchinson, M. F.: A New Procedure for gridding elevation and stream line data with automatic removal of spurious pits, J. Hydrol., 106, 211-232, 1989.

Jamieson, S. S. R. and Sudgen, D. E.: Landscape evolution in Antarctica, in: Antarctica: A Keystone in a Changing World, edited by: Cooper, A. K., Barrett, P. J., Stagg, H., Storey, B., Stump, E., Wise, W., and the 10th ISAES editorial team, Proceedings of the 10th International Symposium on Antarctic Earth Sciences, The National Academies Press, Washington, D.C., 3954, 2008.

Jamieson, S. S. R., Sudgen, D. E., and Hulton, N. R. J.: The evolution of the subglacial landscape of Antarctica, Earth Planet. Sc. Lett., 293, 1-27, 2010.

Jordan, T. A., Ferraccioli, F., Ross, N., Corr, H. F. J., Leat, P. T., Bingham, R. G., Rippin, D. M., le Brocq, A., and Siegert, M. J.: Inland extent of the Weddell Sea Rift imaged by new aerogeophysical data, Tectonophysics, 585, 137-160, 2013.

Joughin, I., Bamber, J. L., Scambos, T., Tulaczyk, S., Fahnestock, M., and MacAyeal, D. R.: Integrating satellite observations with modelling: basal shear stress of the Filchner-Ronne ice streams, Antarctica, Philos. T. Roy. Soc. A, 364, 1795-1814, 2006.

Joughin, I., Tulaczyk, S., Bamber, J. L., Blankenship, D., Holt, J. W., Scambos, T., and Vaughan, D. G.: Basal conditions for Pine Island and Thwaites Glaciers, West Antarctica, determined using satellite and airborne data, J. Glaciol., 55, 245-257, 2009.

Joughin, I., Smith, B. E., and Medley, B.: Marine ice sheet collapse potentially under way for the Thwaites Glacier Basin, West Antarctica, Science, 344, 735-738, 2014.

Kerr, A., Sugden, D. E., and Summerfield, M. A.: Linking tectonics and landscape development in a passive margin setting: the Transantarctic Mountains, in: Geomorphology and Global Tectonics, Summerfield, M. A., John Wiley \& Sons, Chichester, 303-319, 2000.

King, E. C., Hindmarsh, R. C. A., and Stokes, C. R.: Formation of mega-scale glacial lineations observed beneath a West Antarctic ice stream, Nat. Geosci., 2, 585-588, 2009.

Klemsdal, T.: Coastal classification and the coast of Norway, Norsk Geografisk Tidsskrift, 36, 129-152, 1982.

Le Brocq, A. M., Ross, N., Griggs, J. A., Bingham, R. G., Corr, H. F. J., Ferraccioli, F., Jenkins, A., Jordan, T. A., Payne, A. J., Rippin, D. M., and Siegert, M. J.: Evidence from ice shelves for channelized meltwater flow beneath the Antarctic Ice Sheet, Nat. Geosci., 6, 945-948, 2013.

Lee, H. M., Lee, J. I., Lee, M. J., Kim, J., and Choi, S. W.: The A-type Pirrit Hills Granite, West Antarctica: an example of magmatism associated with the Mesozoic break-up of the Gondwana supercontinent, Geosci. J., 16, 421-433, 2012.

Li, X., Sun, B., Siegert, M. J., Bingham, R. G., Tang, X. Y., Zhang, D., Cui, X. B., and Zhang, X. P.: Characterization of subglacial landscapes by a two-parameter roughness index, J. Glaciol., 56, 831-836, 2010.

Montgomery, D. R., Balco, G., and Willett, S. D.: Climate, tectonics and the morphology of the Andes, Geology, 29, 579-582, 2001.

Näslund, J.-O.: Landscape development in western and central Dronning Maud Land, East Antarctica, Antarct. Sci., 13, 302311, 2001.

Pedersen, V. K., Egholm, D. L., and Nielsen, S. B.: Alpine glacial topography and the rate of rock column uplift: a global perspective, Geomorphology, 122, 129-139, 2010.

Peters, L. E., Anandakrishnan, S., Alley, R. B., Winberry, J. P., Voigt, D. E., Smith, A. M., and Morse, D. L.: Subglacial sediments as a control on the onset and location of two Siple Coast ice streams, West Antarctica, J. Geophys. Res.-Solid, 111, B01302, doi:10.1029/2005jb003766, 2006.

Porter, S. C.: Some geological implications of average Quaternary glacial conditions, Quatern. Res., 32, 245-261, 1989.

Rignot, E., Mouginot, J., and Scheuchl, B.: Ice flow of the Antarctic ice sheet, Science, 333, 1427-1430, 2011.

Rippin, D. M., Vaughan, D. G., and Corr, H. F. J.: The basal roughness of Pine Island Glacier, West Antarctica, J. Glaciol., 57, 6776, 2011.

Rippin, D. M., Bingham, R. G., Jordan, T. A., Wright, A. P., Ross, N., Corr, H. F. J., Ferraccioli, F., Le Brocq, A., Rose, K. C., and Siegert, M. J.: Basal roughness of the Institute and Möller ice streams, West Antarctica: determining past ice dynamical regimes, Geomorphology, 214, 139-147, 2014.

Rose, K. C., Ferraccioli, F., Jamieson, S. S. R., Bell, R. E., Corr, H., Creyts, T. T., Braaten, D., Jordan, T. A., Fretwell, P. T., and Damaske, D.: Early East Antarctic Ice Sheet growth recorded in the landscape of the Gamburtsev Subglacial Mountains, Earth Planet. Sc. Lett., 375, 1-12, 2013.

Rose, K. C., Ross, N., Bingham, R. G., Corr, H. F. J., Ferraccioli, F., Jordan, T. A., Le Brocq, A., Rippin, D. M., and Siegert, M. J.: A temperate former West Antarctic ice sheet suggested by an extensive zone of subglacial meltwater channels, Geology, 42, 971-974, 2014.

Ross, N., Bingham, R. G., Corr, H. F. J., Ferraccioli, F., Jordan, T. A., Le Brocq, A., Rippin, D. M., Young, D., Blankenship, D. D., and Siegert, M. J.: Steep reverse bed slope at the grounding 
line of the Weddell Sea sector in West Antarctica, Nat Geosci., 5, 393-396, 2012.

Ross, N., Jordan, T. A., Bingham, R. G., Corr, H. F. J., Ferraccioli, F., Le Brocq, A., Rippin, D. M., Wright, A. P., and Siegert, M. J.: The Ellsworth Subglacial Highlands: inception and retreat of the West Antarctic Ice Sheet, Geol. Soc. Am. Bull., 126, 3-15, 2014.

Scambos, T. A., Haran, T. M., Fahnestock, M. A., Painter, T. H., and Bohlander, J.: MODIS-based Mosaic of Antarctica (MOA) data sets: Continent-wide surface morphology and snow grain size, Remote Sens. Environ., 111, 242-257, 2007.

Siegert, M. J., Taylor, J., and Payne, A. J.: Spectral roughness of subglacial topography and implications for former ice-sheet dynamics in East Antarctica, Global Planet. Change, 45, 249-263, 2005.

Siegert, M. J., Ross, N., Corr, H., Kingslake, J., and Hindmarsh, R.: Late Holocene ice-flow reconfiguration in the Weddell Sea sector of West Antarctica, Quaternary Sci. Rev., 78, 98-107, 2013.

Siegert, M. J., Ross, N., Corr, H., Smith, B., Jordan, T., Bingham, R. G., Ferraccioli, F., Rippin, D. M., and Le Brocq, A.: Boundary conditions of an active West Antarctic subglacial lake: implications for storage of water beneath the ice sheet, The Cryosphere, 8, 15-24, doi:10.5194/tc-8-15-2014, 2014.

Storey, B. C. and Dalziel, I. W. D.: Outline of the structural and tectonic history of the Ellsworth Mountains-Thiel Mountains ridge, West Antarctica, in: Gondwana Six; Structure, tectonics, and geophysics, edited by: McKenzie, G. D., AGU Geophysical Monograph, Washington, D.C., 117-128, 1987.

Storey, B. C., Hole, M. J., Pankhurst, R. J., Millar, I. L., and Vennum, W.: Middle Jurassic within-plate granite in West Antarctica and their bearing on the break-up of Gondwanaland, J. Geol. Soc., 145, 999-1007, 1988.

Storey, B. C., Leat, P. T., and Ferris, J. K.: The location of mantle plume centres during the initial stages of Gondwana break-up, Geol. Soc. Am. Special Paper, 352, 71-80, 2001.

Strahler, A. N.: Hypsometric (area-altitude) analysis of erosional topography, Geol. Soc. Am. Bull., 63, 1117-1142, 1952.
Studinger, M. and Miller, H.: Crustal structure of the FilchnerRonne shelf and Coats Land, Antarctica, from gravity and magnetic data: Implications for the breakup of Gondwana, J. Geophys. Res., 104, 20379-20394, 1999.

Sugden, D. E. and John, B. S.: Glaciers and Landscape, Edward Arnold, London, 1976.

Sugden, D. E., Denton, G. H., and Marchant, D. R.: Landscape evolution of the Dry Valleys, Transantarctic Mountains: tectonic implications, J. Geophys. Res., 100, 9949-9967, 1995.

Taylor, J., Siegert, M. J., Payne, A. J., and Hubbard, B.: Regionalscale bed roughness beneath ice masses: measurement and analysis, Comput. Geosci., 30, 899-908, 2004.

Wilson, D. S. and Luyendyk, B. P.: Bedrock plateaus within the Ross Embayment and beneath the West Antarctic Ice Sheet, formed by marine erosion in Late Tertiary time, in: Antarctica: contribution to global earth sciences, edited by: Fütterer, D. K., Damaske, D., Kleinschmidt, G., Miller, H., and Tessensohn, F., Springer-Verlag, Berlin, 123-128, 2006 a.

Wilson, D. S. and Luyendyk, B. P.: Bedrock platforms within the Ross Embayment, West Antarctica: hypotheses for ice sheet history, wave erosion, Cenozoic extension and thermal subsidence, Geochem. Geophy. Geosy., 7, 1-23, 2006b.

Wright, A. P., Le Brocq, A. M., Cornford, S. L., Bingham, R. G., Corr, H. F. J., Ferraccioli, F., Jordan, T. A., Payne, A. J., Rippin, D. M., Ross, N., and Siegert, M. J.: Sensitivity of the Weddell Sea sector ice streams to sub-shelf melting and surface accumulation, The Cryosphere, 8, 2119-2134, doi:10.5194/tc-8-21192014, 2014.

Young, D. A., Wright, A. P., Roberts, J. L., Warner, R. C., Young, N. W., Greenbaum, J. S., Schroeder, D. M., Holt, J. W., Sugden, D. E., Blankenship, D. D., van Ommen, T. D., and Siegert, M. J.: A dynamic early East Antarctic Ice Sheet suggested by ice-covered fjord landscapes, Nature, 474, 72-75, 2011. 